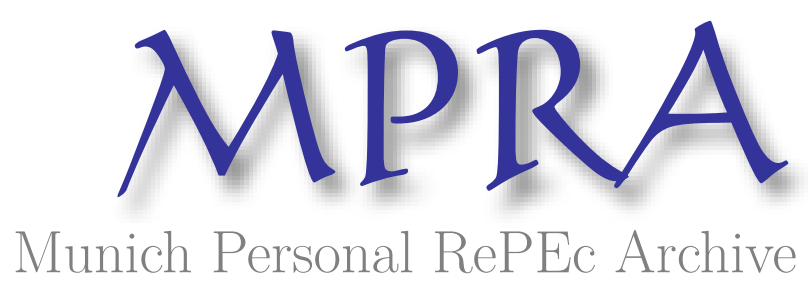

\title{
Financial Inclusion and Economic growth: An International Evidence
}

Vo, Duc and Vo, Anh

Ho Chi Minh City Open University, Vietnam

6 December 2019

Online at https://mpra.ub.uni-muenchen.de/103282/

MPRA Paper No. 103282, posted 20 Oct 2020 08:01 UTC 


\section{Financial Inclusion and Economic Growth: An International Evidence ${ }^{1}$}

\section{Loan Thi-Hong Van, Anh The Vo, Nhan Thien Nguyen, Duc Hong Vo ${ }^{2}$}

Business and Economics Research Group

Ho Chi Minh City Open University Vietnam (NAFOSTED) under grant number 502.01-2019.18.

2 Corresponding author can be contacted at duc.vhong@ou.edu.vn 


\title{
Financial Inclusion and Economic Growth: An International Evidence
}

\begin{abstract}
Many emerging markets in the ASEAN region including Vietnam and Thailand have adopted policies focusing on financial inclusion in recent years. These policies have attracted great attention from scholars, policy makers and regulators as financial inclusion has theoretically been acknowledged to have positive effect on economic growth. However, empirical evidence appears to be very limited, in particular for emerging markets. This paper is conducted to provide a more comprehensive insight about the important link between financial inclusion and economic growth in emerging markets. First, a multidimensional index of financial inclusion is constructed from various indicators so that we can comprehensively measure a level of financial inclusion across countries at the international level. Second, based on this newly developed index, the panel econometric technique is utilized to estimate the impact of financial inclusion on economic growth. Our finding supports a positive relationship between financial inclusion and economic growth. A stronger relationship between financial inclusion and economic growth is found for countries with low income and a relatively lower degree of financial inclusion. Findings from our paper support policy implications that financial inclusion should be implemented for promoting economic growth and development in the emerging markets such as Vietnam.
\end{abstract}

Key words: Financial inclusion, panel data, economic growth

JEL Classifications: C33, C43, G28, O47 


\section{Introduction}

A topic of interest among academics, policy makers and regulators emerged in recent years in the emerging markets would probably be financial inclusion, commonly referred to as the expansion of financial systems, financial services, or financial products to provide a more convenient access to adults in the society. Financial inclusion helps broaden financial network in order to create an efficient financial flow within a country's border. The inclusion is expected to improve people's likelihood, alleviate poverty and enhance economic growth and development. Statistics have illustrated that many nations have recorded to set financial inclusion implementation as a formal goal (Sahay et al. 2015) to support their economic growth and development.

There has been no conclusive definition of financial inclusion. World Bank defines financial inclusion as the degree that households and small enterprises could gain an access to financial services such as deposits, loans, payments, remittances and insurance. According to the Consultative Group to Assist the Poor (CGAP)'s report in 2011, financial inclusion means that formal financial services - such as deposit and savings accounts, payment services, loans, and insurance - are readily available to consumers and that they are actively and effectively using these services to meet their specific needs. Cihak, Mare and Melecky (2016) refers financial inclusion to a wide range of financial services that individuals and firms have a tendency to utilize rather than the ability of access to financial services. The later does not reveal the actual use of these services from individuals and firms for their business or their benefits and the term of "access" is so general that various dimensions have been used to capture.

The motivations for this paper are the emergence of an ongoing practical debate and the lack of empirical studies on the important link between financial inclusion and economic growth. The paper aims to fill the research gap with a significant contribution to the existing research, especially 
at international levels. Unlike most previous studies which used available cross-section national data to analyze the relationship between financial inclusion and economic growth, our paper utilizes panel data and its appropriate econometric methods. In doing so, a multidimensional index of financial inclusion is constructed. The three-year average of data is utilised so that we can obtain as many observations as practical. As such, we could examine the relationship between financial inclusion and economic growth at the international level. Our findings would provide policy makers, regulators as well as academics with valid and convincing evidence on the debate over the impact of financial inclusion on economic growth. We also note that the level of economic development (for developed and developing nations) as well as the degree of financial inclusion can significantly affect the relationship. As such, the research sample is then divided in terms of the level of income and the degree of financial inclusion so that the relationship between financial inclusion and economic growth is revisited for a robust understanding.

The paper is structured as follows. Following the Introduction, Section 2 briefly examines the literature review in relation to relevant theories and empirical evidence. Research methodology is presented in Section 3. Data and empirical findings from this paper are examined and discussed in Section 4 of the paper, followed by the Concluding remarks in Section 5.

\section{Literature review}

There have been two main strands of research in the field of financial inclusion. The first school of thoughts is a reflection of various financial inclusion definitions from many studies integrating several different dimensions such as access, availability, usage, or barrier into a measure. Using data from the Financial Global Findex (FGF) database and Financial Access Survey (FAS), effort has been made to develop a comprehensive index of financial inclusion that could take various dimensions into account. Examples include the financial access index (Honohan 
2008; Rojas-Suarez 2010), the multi-dimensional index (Camara and Tuesta 2014; Kim 2016; Park and Mercado 2015; Sarma 2008, 2012; Wang and Guan 2017) or the composite index (Amidzic, Masssara and Mialou 2014; Demirguc-Kunt and Klapper 2012). Camara and Tuesta (2014) consider a framework for measuring the degree of financial inclusion at country level using the information about the demand and supply. Sahay et al. (2015) present another analysis using different aspects of financial inclusion measurements. Fungacova and Weill (2014) approach the demand term of financial services to interpret financial inclusion, using China as a case of study. Mehrotra and Yetman (2015) discuss financial inclusion and provide implications for central banks throughout approaching the financial accessing ability. It is imperative that a comprehensive measure for financial inclusion not only helps policymaker control progress of initiatives towards financial inclusion, but also provides academics with a valid proxy for hypothesis testing purposes (Sarma 2012).

Based on the constructed index of financial inclusion, another strand of empirical studies focuses on either analyzing the factors causing the level of financial inclusion at country levels (Chakravarty and Pal 2013; Fungacova and Weill 2014; Rojas-Suarez 2010; Sarma 2012; Wang and Guan 2017) or investigating the impact of financial inclusion on other macroeconomic variables (Ahamed and Mallick 2017; Chauvet and Jacolin 2017; Cihak et al. 2016; Garcia and Jose 2016, Morgan and Pontines 2017, Vo et al. 2019a), income inequality and economic growth (Kim, 2016; Kim, Yu and Hassan 2018; Park and Mercado 2015; Turegano and Herrero 2018) and even household levels (Lopez and Winkler 2017; Swamy 2014; Zhang and Posso 2017). Most of these studies have adopted the cross-section data for the analysis.

Demirguc-Kunt and Klapper (2012) have recently carried out a review of empirical evidence regarding financial inclusion. Those authors consider that the link among financial inclusion, 
inequality, and economic growth is not well understood because of the main following reasons. The first reason is the availability of data. Two sources are widely used including: (i) Financial Global Findex (FGF) database by the World Bank and (ii) Financial Access Survey (FAS) from the International Monetary Fund (IMF). The FGF is only available in two distinct years of 2011 and 2014, while the FAS database started in 2004. The lack of data availability has prevented empirical analyses to examine the impact of financial inclusion on macroeconomic variables, income inequality, or economic growth. It is because a robust analysis on these issues requires a long time series data. Another possible reason which effectively limits an examination of financial inclusion to economic growth is the initiatives towards financial inclusion have recently emerged in the economic policies for many countries. Yoshino and Morgan (2018), at the Seoul Summit in 2010, noted that G20 leaders have approved the Financial Inclusion Action Plan and later established the Global Partnership for Financial Inclusion (GPFI) to promote the financial access agenda. Later in 2014, an updating agenda was made with a review of GPFI process, a review of ongoing actions and an adoption of new initiatives. In the initiative of the 2020 Universal Financial Access, involving agents (such as the World Bank Group and the IFC) confirmed a commitment that would offer financial access to transaction for up to 1 billion adults via targeted interventions. In addition, a dedicated forum was established by Finance Ministers in the Asia-Pacific Economic Cooperation (APEC) for a discussion on financial inclusion issues. It has been promoted as a strategic policy in many developing countries, especially in the Association of Southeast Asian Nations (ASEAN) region to provide low-income households and small firms with an equal opportunity to access financial services. 


\subsection{Financial Inclusion Measurement}

Scholars have incorporated different dimensions of financial inclusion into a unique index in the first strand of theoretical and empirical studies. According to Kempson, Atkinson and Pilley (2006), a good measure of financial inclusion should include three criteria, including (i) the ability to incorporate as many dimensions as practical, (ii) simple calculations, and (iii) the comparability across countries.

In Caamara and Tuesta (2014)'s analysis, the degree of financial inclusion was developed based on three fundamental dimensions including usage, barrier and access. First, the usage dimension was considered using three indicators, namely (i) owning at least one financial product, (ii) having savings accounts; and (iii) having a loan with a formal financial institution. The second dimension of barrier refers to obstacles that prevent individuals from accessing formal financial services. Four indicators including the distance, affordability, documentation requirements and trust are generally utilized. Finally, a measure of the access dimension utilized four indicators including either the number of automated teller machines (ATMs) or numbers of commercial bank branches over a unit, say 100,000 adults or $1,000 \mathrm{~km}^{2}$. The data at the country level comes from a Global Findex database by World Bank and a Financial Access Survey (FAS) from the International Monetary Fund (IMF). All dimensions are then combined to produce an index of financial inclusion with the application of two-stage principal component analysis (PCA). Similarly, Mialou, Amidzic and Massara (2017) computed a composite index of financial inclusion with the use of the factor analysis method. The method allows a capacity to respond criticisms in relation to the weighting assessment of indicators and dimensions.

Sarma (2008) constructed an index of financial inclusion on the basis of a wide range of indicators, mainly regarding to the banking sector such as availability, usage, and banking 
penetration. These indicators are combined into an index for a specific country in a single year. The index was developed on the ground of the normalized inverse Euclidean distance. The authors considered that using Euclidean distance method is convenient to construct an index which satisfies necessary mathematical properties and simple calculations. Sarma (2012) modified, updated, and used the index to examine its correlation with economic development. Utilizing the idea of inverse Euclidean distance, Park and Mercado (2015) established the similar multidimensional index as Sarma (2008). However, an average of seven years is used for financial inclusion indicators rather than using a particular year. 180 countries were utilized in the analysis. The level of financial inclusion for these countries were then ranked for comparison purposes. On the basis of Sama (2008) framework, Wang and Guan (2017) used two dimensions of access and usage to construct their own index of financial inclusion. However, in the analysis, these two dimensions were weighted with the coefficient of variation (CV). The $\mathrm{CV}$ is calculated using the proportion of the standard deviation to the mean value and the weight of each dimension is defined as the ratio of its $\mathrm{CV}$ to total of all dimensions' $\mathrm{CV}$. Findings from their paper indicate that the level of financial inclusion in developed countries in Europe and North America is reported to be higher than in less developed nations in Africa and Asia. Kim (2016) used three dimensions penetration, availability, and usage with an equal weight. The framework proposed by Sarma (2008) has received a great attention of scholars in the construction of index of financial inclusion, although the dimensions adopted vary across studies.

\subsection{Financial Inclusion and Economic Growth}

The link among financial inclusion, macroeconomic variables, income inequality, as well as the household income levels has been acknowledged in previous studies, but in this paper, we put our focus on economic growth. From financial perspectives, Levine (2005) provided a comprehensive 
review of how financial systems with various functions impact the decision of savings and investment, thus enhancing economic growth. Five core functions include (i) the production of ex ante information about possible investments, (ii) the control of investment and the implication of corporate governance, (iii) the trading, diversification, and management of risks, (iv) the mobilization and pooling of savings, and (v) the exchange of goods and services. These functions contribute to economic growth via a more efficient allocation of resources, a more rapid accumulation of physical and human capital, and a faster technological process (Goyal et al. 2004).

The relationship between financial inclusion and economic growth can also be considered from the perspectives of financial intermediary functions which allow alleviating the problem of information asymmetry, thus facilitating transactions and promoting economic growth. Levine, Loayza, and Beck (2000) considered that there is a positive impact from the development of financial intermediary on economic growth and a heterogeneous legal and accounting system appears to explain the different level of financial development across countries. Bruhn and Love (2014) used a natural experiment in Mexico to examine the impact of the opening of new commercial banks and an increased access to credit from low-income individuals. The result reveals that an increased access to financial services would lead to an improvement in income levels, an investment on informal business and an unemployment rate.

It should be noted that determining a direction between financial inclusion and economic growth is challenging as they may mutually affect each other. On the one hand, financial inclusion would positively affect economic growth thanks to better access to financial services for firms that may be financially constrained, boosting them to be profitable, and finally resulting in economic development. Cihak et al. (2016) document that a considerably higher growth rate is experienced in sectors which tend to rely on external finance in countries having greater financial depth. In this 
sense, financial development positively affects economic growth by reducing firms' financial constraints. With an access to proper financial services, the poor or disadvantaged have equal opportunities for an investment in their education and physical assets, thus resulting in a reduction of income inequality and a boost of economic development (Mehrota and Yetman 2015).

Kim, Yu, and Hassan (2018) find the positive influence of financial inclusion on economic development in the Organization of Islamic Cooperation (OIC) countries by applying the dynamic panel analysis. Also, the impulse response functions derived from the panel vector autoregression confirm the positive relationship and the mutual causalities between the financial inclusion and economic growth is documented based on the panel Granger causality tests. Kim (2016) find a positive impact of financial inclusion on economic growth in OECD countries via an indirect channel of income inequality. The positive impact is much stronger in the low-income and highfragility country. The classification into the low- and high-income (fragility) is based on the level of income (the share of non-performing loans over total bank loans) in a year that is lower or higher its median value.

On the other hand, financial inclusion is influenced by the development of an economy as higher economic growth often leads to greater financial development. Sarma and Pais (2011) try to answer the question in relation to the link between economic development and the all-inclusive financial system. Based on the index of financial inclusion, these authors empirically find what factors cause the different degree of financial inclusion across country. It is found that the level of financial inclusion is closely related to that of human development and considerably attributed by such social-economic and infrastructure elements as income, inequality, literacy, urbanization and physical infrastructure. Banking sector factors are also taken into account. The health of the banking system, measured either by the share of the non-performing assets to total assets or by the 
capital asset ratio of the banking system, has an ambiguous effect on the degree of financial inclusion. The ownership pattern, proxied by the proportion of foreign banks and government owned banks in the total assets of banking system, has a negative impact. Admittedly, Wang and Guan (2017) reveals that the level of individials' income, education, and the use of comumincations equipments play an vitally important role in explaning a country's degree of financial inclusion and that other macroeconomic-related factors, namely financial depth and bank health status, are found to be a significant determinant.

\section{Research Methodology}

\subsection{Financial Inclusion Measurement}

Previous studies have constructed an index of financial inclusion using survey data up to 148 countries from the Global Findex database by World Bank (Amidzic, Masssara and Mialou 2014; Demirguc-Kunt and Klapper 2012). A substantial advantage of using survey data for computing a combined or composite measures of financial inclusion is worldwide coverage, cross-country comparative purposes. Yet, it appears to be difficult for a worldwide survey to be conduct at regular intervals owing to substantial cost and time. Therefore, a measure of financial inclusion using survey data may not be easily available at an interval and periodic basis (Sarma 2012). Additionally, the IMF introduces a new board-based index of financial development with the coverage of 183 countries on annual frequency over a 1980-2013 period. This database offers a useful analytical tool for researchers and policy makers (Svirydzenka 2016). Its focus is on the development of financial institutions and financial market in terms of the depth, access, and efficiency rather than on financial inclusion. To capture partially the function of financial inclusion, it is more appropriate to use its own indicators than using a broaden aspect of financial development. 
From literature perpecstives, several indicators have been adopted for the measurement of the financial inclusion index. The most widely used would be the number of bank accounts per 1,000 adults, the number of bank branches (per 100,000 adults), the number of ATMs (per $100,000)$, the amount of bank credit, the amount of bank deposits.

We use three indecators - the number of commercial bank branches per 100,000 adults, the number of ATMs per 100,000 adults, and the ratio of bank credit for private sector to GDP for the measurement of financial inclusion. The two former indicators demonstrate the availability of banking sectors and the latter indicator illustrate the use of banking system. As the share of total credit over GDP is a much broader indicator of financial conditions, we restrict the usage dimension by using the ratio of bank credit for private sector, which reflect the nature of financial inclusion more appropriately. The selection of these dimensions is mainly attributable to data availability and recent development in the literature of measuring the level of financial inclusion (see Kim, 2016). We do acknowledge the importance of usage indicators. Without taking them into account, it may raise a potentially unrepresentative index as ATMs and branches ilustrate the availability of banking sector.

After computing the three-year average value for each of three indicators, the initial step is to calculate the dimesion index. Following Sarma (2008)'s specification, the equation for the dimension index is specified as follows:

$$
d_{i}=\frac{A_{i}-m_{i}}{M_{i}-m_{i}}, i=1,2,3
$$

Where $A_{i}$ is the actual value of dimension $i, m_{i}$ is the minimum value of dimension $i$, and $M_{i}$ is the maximum value of dimension i. Equation (1) ensures the $d_{i}$ ranges between 0 and 1 . The higher value of $\mathrm{d}_{\mathrm{i}}$, the higher degree of dimension i a country obtains. The index of financial 
inclusion (IFI) is calculated by the norminalized inverse Euclidean distance of point $D_{i}=\left(d_{i}, d_{i}, d_{i}\right)$ in equation ( 1 ) from the ideal point $I=(1,1,1)$. The equation is given as:

$$
I F I_{i}=1-\frac{\sqrt{\left(1-d_{1}\right)^{2}+\left(1-d_{2}\right)^{2}+\left(1-d_{3}\right)^{2}}}{\sqrt{3}}
$$

The numbers are normalized to make it lie between 0 and 1 and the inverse distance means that the higher the index is, the higher degree of financial inclusion a country achieves.

Our index of financial inclusion is calculated on the combination of two approaches by Sarma (2011) and by Park and Mercado (2015). Our proposed index has comparative advantages. First, the proposed index has a characteristics of a calculation with ease, a satisfaction with mathematic properties, and a standardization for hypothesis testing (Sarma 2008, 2012; Park and Mercado, 2015). Second, like preceding studies, we take into different indicators into a unique index so that we can interpret the complex nature of financial inclusion. Using secondary sources enables us to ignore the constraint of data periodic frequency, thus maximizing the data availability at the international level. The index adopts all cross-section countries and timeframe from 2004 to 2015. Also, instead of adopting an approach of taking average data by Park and Mercado (2015), who used the average of the 2004-2012 period to calculate their index of financial inclusion, we use an average of three-year time series to overcome missing data, to enlarge sample size and to ensure sufficient observations. As such, the sample has a time period of four stages including 20042007, 2007-2009, 2009-2012, and 2012-2015.

\subsection{Financial Inclusion and Economic Growth}

To examine the impact of financial inclusion on economic growth on international levels, the model is proposed as followed.

$$
\ln Y_{i, t}=\alpha_{i}+\beta \ln I F I_{i, t}+\gamma_{j} \ln Z_{j, t}+\varepsilon_{i, t}
$$


Where the dependent variable $(\mathrm{Y})$ represents the economic growth, measured by the real per capita gross domestic product (GDPPC). ${ }^{3}$ The independent variable on the right hand side of equation (3) include our concerned variable, the financial inclusion ( $\left(\mathrm{FI}_{\mathrm{i}, \mathrm{t}}\right)$, and other control ones $\left(\mathrm{Z}_{\mathrm{j}, \mathrm{t}}\right) \cdot \gamma_{j}$ is the vector of nuisance parameter and $\varepsilon_{i, t}$ is error terms. The control variables $\left(\mathrm{Z}_{\mathrm{j}, \mathrm{t}}\right)$ consist of the population, the human capital proxied by the ratio of number of secondary schooling to gross students, capital formation, financial direct investment, agricultural share, the trade openness. Like the index of financial inclusion, all these variables are also taken the three-year average.

With the properties of data and with interpretation, we use all the variables in terms of logarithm. The estimated coefficients indicate the relative impact of independent variables on the dependent one. The coefficient of $\beta$ is of our interest, indicating the impact of financial inclusion on economic growth. In other words, a 1 percent change in the index of financial inclusion will lead to a $\beta$ percent change in the growth rate on average.

Another issue to be considered is that the nature of economic growth model often has a dynamic effect, meaning that it is closely related to its previous value. As such, empirical studies should be take the dynamic effect into account. This is typically obtained by adding lagged GDP per capita as an explanatory variable. Thus, the static model in equation (3) is transformed into the dynamic form as follows:

$$
\ln Y_{i, t}=\alpha_{i}+\ln Y_{i, t-1}+\beta \ln I F I_{i, t}+\gamma_{j} \ln Z_{j, t}+\varepsilon_{i, t}
$$

\footnotetext{
${ }^{3}$ We use the real per capita GDP as the representative variable of economic growth rather than GDP. Although GDP are commonly used to measure economic growth, per capita GDP enables us to take into different population size across countries, thus reducing a potential issue of heterogeneity. Also, per capita GDP has been widely considered a growth rate in numerous academic studies (Hajilee, Stringer, and Massoud 2017; Kim, Yu and Hassan 2017 ; Vo et al. $2019 b$, to name a few).
} 
The model contains a lagged dependent variable in a panel setting where cross-sessional fixed effects are included. This creates dynamic panel bias as mentioned by Nickell (1981). It is more appropriate to estimate equation (4) using the system generalized method of moments (GMM) proposed by Blundell and Bond (1998). This method allows to estimate dynamic panel estimator using lagged levels and lagged first-differences as an instrument for a system of equations with first-differences and levels, respectively. Besides accounting for a problem of endogenity, the GMM provides a more robust estimation to measurement errors as compared to the ordinary least squares (OLS). However, it appears to be a short series of a timespan that makes the GMM estimation not well-performed. The bootstrap corrected fixed effects estimation and inference in dynamic panel models can be an alternative. This method estimates the specified model with the fixed effects estimator and corrects its small T bias (see Nickell, 1981) using a simplified but extended version of the approach presented in Everaert and Pozzi (2007). A limitation of this method is the ignorance of invariant variable in the model. Therefore, in an effort to alleviate the bias, we perform the fixed effects regression with a robust error of heteroskedasticity and autocorrelation.

Some authors may try to consider a reverse causal relationship between economic growth and financial inclusion (Kim et al. 2018), while others tend to focus on what factors determine the levels of financial inclusion at country levels (Beck, Demirguc-Kunt and Honohan 2009; Wang and Guan 2017; Samar and Pais 2011). In this paper, we emphasize the impact of financial inclusion on economic growth, however. 


\section{Data and Empirical Results}

\subsection{Data}

The data for the analysis originates from World Bank. The data for financial inclusion is from Global Findex database while other macroeconomic variables is from World Development Indicators. Details of data description is on Table A1 in the Appendix.

\subsection{Financial Inclusion Index}

Table A2 in the Appendix depicts the index for financial inclusion for a total sample of 152 countries. It shows the index of financial inclusion values for 4 periods of time, which include the 2004-2007, 2007-2009, 2009-2012, 2012-2015, and the overall average value. The ranking is relied on the average index. The highest number is for Spain at 0.65 , while the lowest belongs to Guinea at 0.01 . It should be noted that the financial inclusion is recorded to increase in three third period before decreasing in the last one.

Our own calculation obtained a lower value of the index of financial inclusion than those of Park and Mercado (2015) as our numbers range between nearly zero and approximately 0.7. In contrast, the figures reported by Park and Mercado (2015) are in the range from 0.2 to 0.91 . There are two possible explanations, including (i) the approach of taking three-year average data and (ii) the use of the credit for private sector over GDP. Actually, our results are fairly consistent to those of Park and Mercado (2015) in terms of the ranking as indicated in Table A2. The high values of index of financial inclusion fall into developed countries, whereas the low numbers are in respect to developing nations. Thus, our constructed index appears to be valid and reliable for investigating the effect of financial inclusion on economic growth. 
To closely examine the pattern of financial inclusion in different countries of the world as well as to compare our index with those in previous studies, we separate our entire sample into sub-groups based on income dimensions. Based on the 2016's income classification by World Bank, four groups include low-, lower middle-, upper middle-, and high-income countries. Figure 1 indicates the index of financial inclusion in four different periods with four income groups. It can be clearly seen that the higher level of income the country has, the higher magnitude of financial inclusion it accomplishes. The patterns are similar to those in Honohan (2008) and Sarma (2012), who observed the financial inclusion is higher in advanced economies than in emerging and developing ones.

\section{[ Figure 1 ]}

Our multidimensional index of financial inclusion has a wide range of advantages. First, our index is based on a well-known method of Euclidean distance, making it satisfied requirements for mathematical properties. Second, it is impartially consistent to those in other previous empirical studies, affirming its validity in the measurement. Third, the index covers a huge data of 152 nations over the four periods and the country's ranking according to its values of the index of financial inclusion. A great insight about the financial inclusion enables us to investigate the impact of financial inclusion on economic growth at an international level.

\subsection{Financial Inclusion and Economic Growth}

Figure 2 depicts the relationship between financial inclusion and economic growth across countries, with figures presenting an average of three-year data of the index of financial inclusion. An upward sloping line indicates a positive relationship between GDP per capita and financial inclusion. The higher GDP per capita a country is, the higher degree the index of financial inclusion it obtains. 


\section{[ Figure 2 ]}

We show the impact of financial inclusion on economic growth using the index of financial inclusion in Table 1. In the table, the results for the whole sample is indicated in column 1, for the four sub-groups of income levels in the next four columns from column 2 to column 6 , and for the quantile of $25,50-75$, and above 75 of the index of financial inclusion in the last three columns. We also regress the same model for the three dimensions of the index of financial inclusion. Table 2, Table 3, and Table 4 present the results for the number of commercial bank branches per 100,000 adults, the number of ATMs per 100,000 adults, and the ratio of private credit to GDP, respectively. $^{4}$

\section{[ Table 1 ]}

The lagged value of GDP per capita has a positive effect on the current one since all coefficients are found to be positively statistically significant. Similarly, the capital formation has a significantly positive influence on the growth rate. The human capital proxied by the number of schooling and the population growth rate seem to have a marginal impact on the real growth rate of GDP per capita; almost the coefficients are insignificant with one exception. The level development of a country, measured by the 2004's GDP per capital does have an effect on economic growth, but significant coefficients are only observed in the whole sample and the highest quantile. The positive sign supports for the divergence literature of growth rather than the convergence.

\footnotetext{
${ }^{4}$ A couple of little robustness exercises are also covered. The first is to estimate a model without fixed effects - a simple pooled least square estimator. The second is to estimate the model without the lagged dependent variable. Using the index of financial inclusion as well as its three sub-dimensions, the former method almost yields the positive impact of financial inclusion on economic growth not only in the entire sample but also in all the remaining subgroups based on various income levels as well as quantiles. The later method provides an insignificant positive effect. Thus, it is justified that the inclusion of both fixed effects and lagged per capita GDP greatly improves the overall model. The estimation results will be available upon request.
} 
The proportion of government expenditure to GDP appears to be negative and significant for the whole sample, indicating that the more the government spends, the higher degree the GDP per capita are hurt. The impact is more profound in the group of upper middle and high income as well as the moderate level of financial inclusion. This may imply that the government spending generates a crowding-out effect on private investment from households and firms. The impact of trade openness on the growth of GDP per capital varies considerably across the group of income level as well as the degree of financial inclusion, although it is statistically insignificant. Our findings are quite consistent to those in Hassan, Sanchez, and $\mathrm{Yu}$ (2011). Those authors document that economic growth is significantly and positively related to the trade openness but negatively impacted by the government expenditure and the results appears to be robust in six geographical regions as well as two income groups using three measures of financial development, namely the domestic credit provided to private sector, the domestic credit provided by banking sector, and the liquid liabilities. Agriculture seems to be negatively associated with the growth rate, but the effect is found in the low and high-income group as well as the middle level of financial inclusion.

Concerning the effect of financial inclusion on economic growth, the results shows a positive link between the two variables on average. The effect is more profound when it comes to the lowincome group and the middle level of financial inclusion, with less degree of impact being in the sub-sample of low level of financial inclusion. Our findings are in line with those in Kim et al. (2018), who shows a positive influence of financial inclusion on economic growth.

\section{[ Table 2 ]}

[ Table 3 ]

[ Table 4 ] 
When it comes to the three dimensional indicators of the index of financial inclusion, we observe a nearly similar pattern on the impact of financial inclusion on economic growth. Specifically, an increase of the number of ATM per users are found to have a positive effect on economic growth, but when the degree of income or financial inclusion is controlled, the coefficients are statistically insignificant. An increase in opening the number of bank branches provides more profound effects, especially for countries with low income and having median degree of financial inclusion. It is no conclusion for the impact of a higher credit access to the economic growth. Our results are in line with Bruhn and Love (2014)'s study, which document the benefits of the opening of new commercial banks on citizens in Mexico.

\section{Concluding Remarks}

An increasing trend of pursuing the strategy of financial inclusion in recent years in many parts of the world has attracted a number of scholars. Although the influence of financial inclusion on economic growth have been acknowledged in the literature, empirical studies on this concern seems to be immature with a focus on the Asia or Africa region. This paper is conducted to give better insights on the link between financial inclusion and economic growth at the international level.

Due to a lack of complete data on financial inclusion, we construct a multidimensional index of financial inclusion internationally on the ground of previous empirical studies. We take advantage of data availability from different sources and use a 3-year average to increase sample size. This allows us to fully examine the relationship between financial inclusion and economic growth in the international level. In addition, we apply the panel econometric technique to estimate the impact of financial inclusion on economic growth. The finding from this study supports the positive relationship between financial inclusion and economic growth. A stronger magnitude of 
this relationship has been documented in countries with the low income and at a lower degree of financial inclusion. This evidence is of importance, providing that the implementation of financial inclusion in recent years in developing and emerging countries is a proper strategy for promoting economic growth.

This research bears limitations. First, there are no institutional controls in the growth model. Countries with different institution frameworks may target different levels of financial inclusion and thus, it may affect the magnitude of the link between financial inclusion on economic growth. Although we have divided our sample in terms of the level of financial inclusion as well as the level of income, it is worth noting the institutional factor in the analysis. Second, the problem of dynamic panel bias, commonly known as Nickel bias, appears to be another weakness of this paper as the robust fixed effects estimation did not solve the problem radically. These drawbacks motivate an interesting study in the future in the field of financial inclusion and its effect on macroeconomic factors. 


\section{Reference}

Ahamed, MM and SK Mallick (2017). Is financial inclusion good for bank stability? International evidence. Journal of Economic Behavior and Organization.

Beck, T, A Demirgüç-Kunt and P Honohan (2009). Access to financial services: Measurement, impact, and policies. The World Bank Research Observer, 24(1), 119-145.

Blundell, R and S Bond (1998). Initial conditions and moment restrictions in dynamic panel data models. Journal of Econometrics, 87, 115-143.

Bruhn, M and I Love (2014). The real impact of improved access to finance: Evidence from Mexico. The Journal of Finance, 69(3), 1347-1376.

Camara, N and D Tuesta (2014). Measuring financial inclusion: A multidimensional index.

Chakravarty, SR and R Pal (2013). Financial inclusion in India: An axiomatic approach. Journal of Policy Modeling, 35(5), 813-837.

Chauvet, L and L Jacolin (2017). Financial inclusion, bank concentration, and firm performance. World Development, 97, 1-13.

Cihak, M, DS Mare and M Melecky (2016). The nexus of financial inclusion and financial stability a study of trade-offs and synergies. Policy Research Working Paper, (June), 1- 45.

Demirguc-Kunt, A and L Klapper (2012). Measuring financial inclusion: The global findex database. World Bank Policy Research Working Paper, 6025 (April), 1-61.

Everaert, G. and L Pozzi (2007). Bootstrap-based bias correction for dynamic panels. Journal of Economic Dynamics \& Control, 31,1160-1184. 
Fungacova, Z and L Weill (2014). Understanding financial inclusion in China. China Economic Review, 34, 196-206.

Goyal, R, S Creane, AM Mobarak and R Sab (2004). Financial sector development in the Middle East and North Africa. International Monetary Fund Working Paper.

Garcia, MJR and M Jose (2016). Can financial inclusion and financial stability go hand in hand? Economic Issues, 21(2), 81-103.

Hassan, MK, B Sanchez and JS Yu (2011). Financial development and economic growth: New evidence from panel data. The Quarterly Review of Economics and Finance, 51(1), 88-104.

Hajilee, M, DY, Stringer and M Metghalchi (2017). Financial market inclusion, shadow economy and economic growth: New evidence from emerging economies. The Quarterly Review of Economics and Finance, 66, 149-158.

Honohan, P (2008). Cross-country variation in household access to financial services. Journal of Banking and Finance, 32(11), 2493-2500.

Kempson, E, A Atkinson and O Pilley (2006). Policy level response to financial exclusion in developed economies: lessons for developing countries.

Kim, DW, JS Yu and MK Hassan (2018). Financial inclusion and economic growth in OIC countries. Research in International Business and Finance, 43, 1-14.

Kim, JH (2016). A study on the effect of financial inclusion on the relationship between income inequality and economic growth. Emerging Markets Finance and Trade, 52(2), 498-512.

Levine, R (2005). Finance and growth: Theory and evidence. Handbook of Economic Growth, 865-934. 
Levine, R, N Loayza and T Beck (2000). Financial intermediation and growth: Causality and causes. Journal of Monetary Economics, 46(1), 31-77.

Lopez, T and A Winkler (2017). The challenge of rural financial inclusion - evidence from microfinance. Applied Economics, 50(14), 1555-1577.

Mehrotra, A and J Yetman (2015). Financial inclusion - issues for central banks. BIS Quarterly Review, (March), 83-96.

Mialou, A, G Amidzic, and A Massara (2017). Assessing countries' financial inclusion standing A new composite index. Journal of Banking and Financial Economics, 2(8), 105-126.

Morgan, PJ and V Pontines (2017). Financial stability and financial inclusion: The case of SME lending. The Singapore Economic Review, 63(1), 1-14.

Nickell, S. (1981). Biases in dynamic models with fixed effects. Econometrica 49(6), 1417-1426.

Park, CY and RV Mercado (2015). Financial inclusion, poverty and income inequality in developing Asia. ADB Economics Working Paper Series, 426, 17.

Rojas-Suarez, L (2010). Access to financial services in emerging powers: Facts, obstacles and policy implications.

Sahay, R, M Cihak, P N'Diaye, A Barajas, S Mitra, A Kyobe... and R Yousefi (2015). Financial Inclusion: Can it Meet Multiple Macroeconomic Goals?. IMF Staff Discussion Notes 15/17.

Sarma M (2008). Index of financial inclusion. ICRIER Working Paper No 215.

Sarma, M (2012). Index of financial inclusion - A measure of financial sector inclusiveness. Berlin Working Papers on Money, Finance and Trade Development, 7, 1-34. 
Sarma, M and J Pais (2011). Financial inclusion and development. Journal of International Development, 23, 613-628.

Svirydzenka, K. (2016). Introducing a new broad-based index of financial development. International Monetary Fund Working Paper Series No 16/5.

Swamy, V (2014). Financial inclusion, gender dimension, and economic impact on poor households. World Development, 56, 1-15.

Turegano, DM and AG Herrero (2018). Financial inclusion, rather than size, is the key to tackling income inequality. The Singapore Economic Review, 63(1), 167-184.

Vo, AT, LTH, Van, DH Vo and M McAleer (2019a). Financial inclusion and macroeconomic stability in emerging and frontier markets. Annals of Financial Economics, 14(02), 1950008.

Vo, DH, TC Nguyen, NP Tran, and AT Vo (2019b). What factors affect income inequality and economic growth in middle-income countries?. Journal of Risk and Financial Management, 12(1), 40 .

Wang, X and J Guan (2017). Financial inclusion: Measurement, spatial effects and influencing factors. Applied Economics, 49(18), 1751-1762.

Yoshino, N and PJ Morgan (2018). Financial inclusion, financial stability and income inequality: Introduction. The Singapore Economic Review, 63(1), 1-7.

Zhang, Q and A Posso (2017). Thinking inside the box: A closer look at financial inclusion and household income. Journal of Development Studies, 1-16. 


\section{Tables and Figures}

Figure 1: Average financial inclusion index in terms of income dimensions

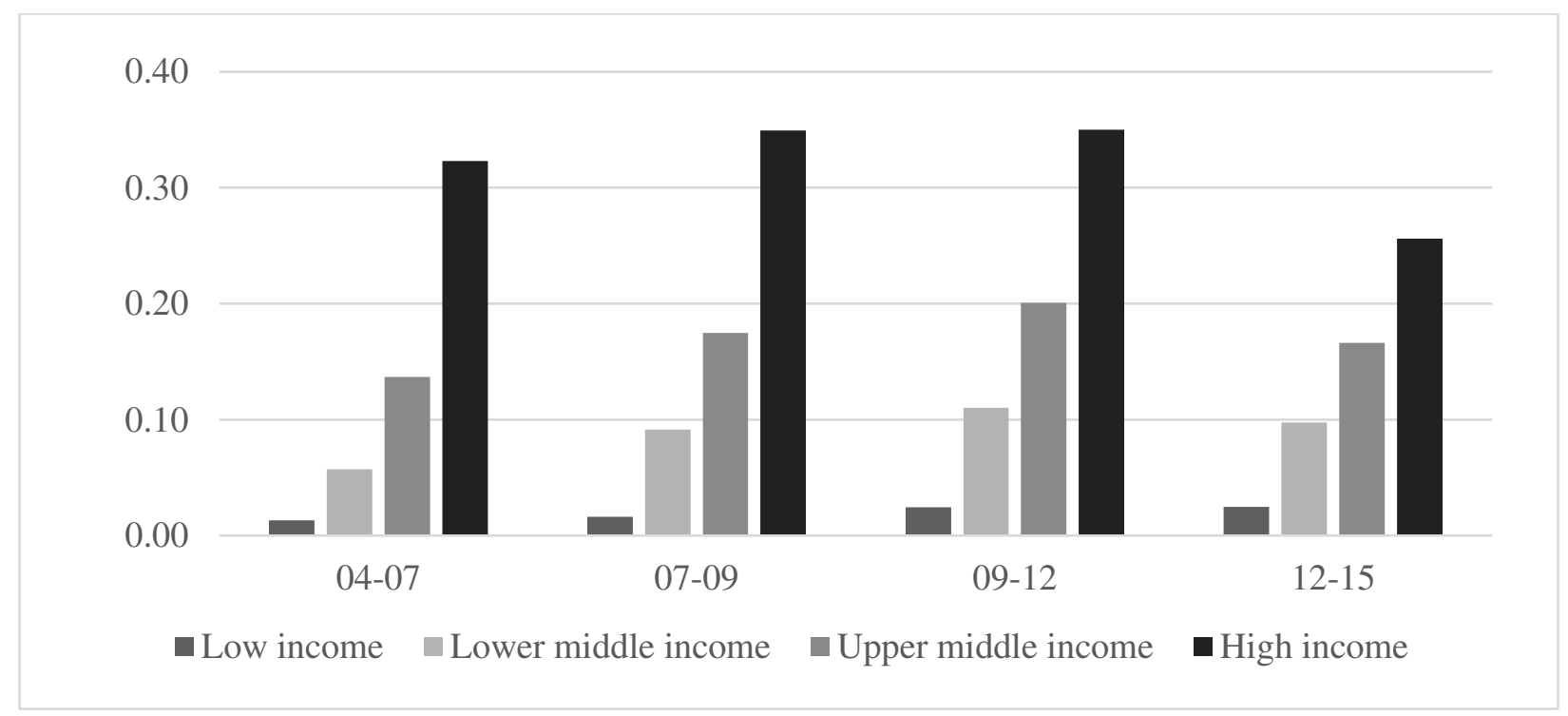

Figure 2: Financial inclusion and GDP per capita

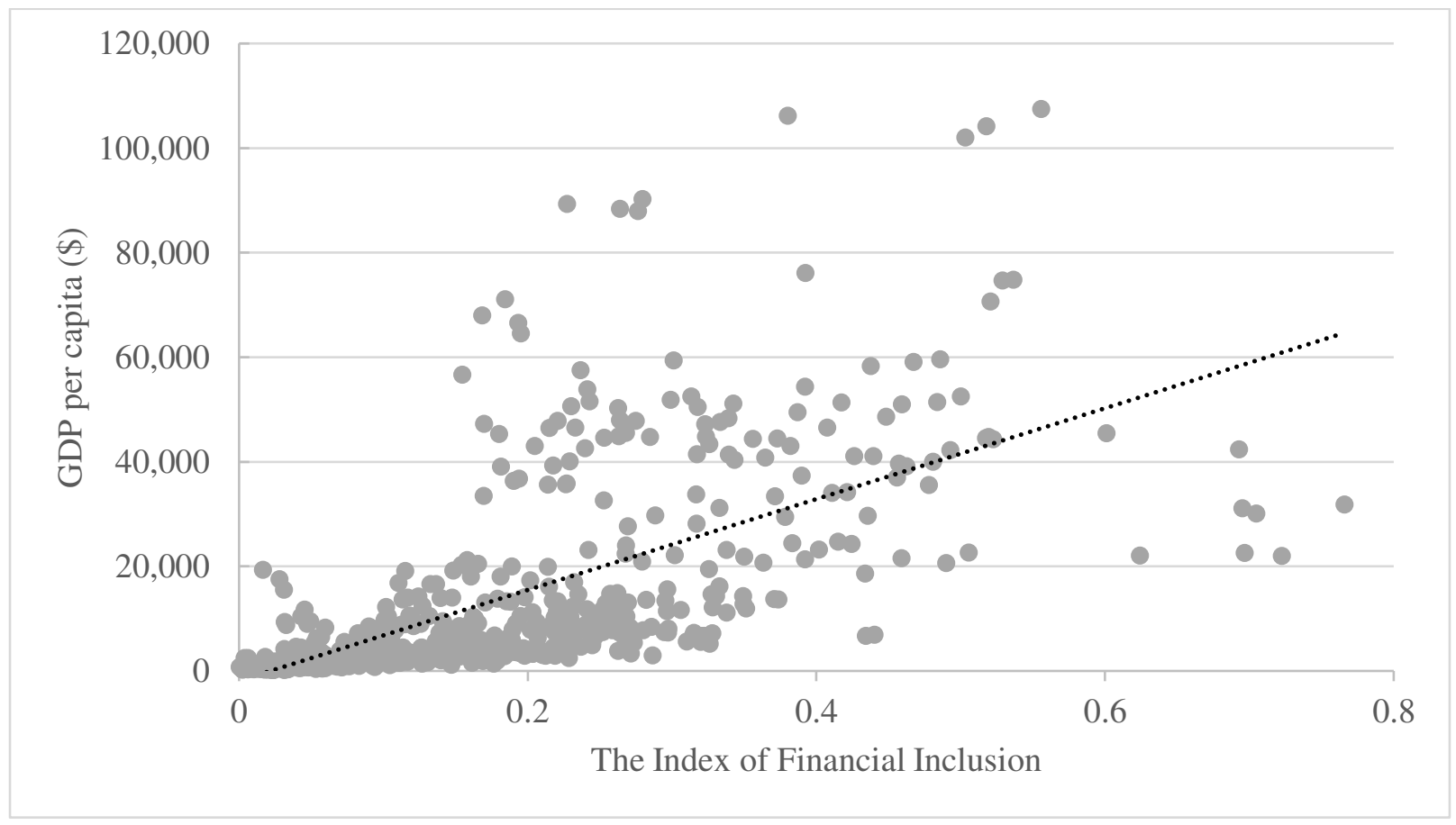


Table A1: Data description

\begin{tabular}{lccccc}
\hline \multicolumn{1}{c}{ Variable } & Observations & Mean & Std. Dev. & Min & Max \\
\hline Index of Financial Inclusion & 581 & 17.81 & 14.01 & 0.04 & 76.57 \\
ATMs & 590 & 41.13 & 40.79 & 0.05 & 283.97 \\
Bank Branches & 599 & 19.00 & 19.39 & 0.30 & 217.69 \\
Private credit/GDP & 606 & 51.91 & 41.62 & 1.47 & 237.46 \\
Real GDPPC 2004 & 608 & $12,405.86$ & $18,066.25$ & 224.52 & $99,778.47$ \\
Population & 608 & 31.12 & 104.78 & 0.05 & $1,293.83$ \\
Schooling & 520 & 82.05 & 26.79 & 12.75 & 164.91 \\
Capital share & 560 & 24.70 & 7.76 & 5.91 & 66.99 \\
Agricultural share & 586 & 11.30 & 11.17 & 0.04 & 64.97 \\
Trade openness & 599 & 70.71 & 35.94 & 16.70 & 336.21 \\
\hline
\end{tabular}


Table A2: Financial Inclusion Index

\begin{tabular}{|c|c|c|c|c|c|c|c|}
\hline Country & 04-07 & 07-09 & $09-12$ & $12-15$ & Average & Ranking & $\begin{array}{c}\text { Income } \\
\text { group }\end{array}$ \\
\hline Afghanistan & 0.006 & 0.014 & 0.013 & 0.005 & 0.009 & 150 & $\mathrm{~L}$ \\
\hline Albania & 0.070 & 0.156 & 0.188 & 0.126 & 0.135 & 85 & UM \\
\hline Algeria & 0.031 & 0.039 & 0.043 & 0.039 & 0.038 & 130 & UM \\
\hline $\begin{array}{l}\text { Antigua and } \\
\text { Barbuda }\end{array}$ & & 0.327 & 0.351 & 0.231 & 0.303 & 26 & $\mathrm{H}$ \\
\hline Angola & 0.018 & 0.044 & 0.080 & 0.073 & 0.054 & 118 & LM \\
\hline Argentina & 0.090 & 0.101 & 0.119 & 0.103 & 0.103 & 99 & UM \\
\hline Armenia & 0.054 & 0.110 & 0.174 & 0.161 & 0.125 & 89 & LM \\
\hline Australia & 0.448 & 0.484 & 0.500 & 0.392 & 0.456 & 8 & $\mathrm{H}$ \\
\hline Austria & 0.323 & 0.323 & 0.333 & 0.275 & 0.314 & 23 & $\mathrm{H}$ \\
\hline Azerbaijan & 0.060 & 0.080 & 0.095 & 0.098 & 0.083 & 109 & UM \\
\hline Bahamas. The & & 0.338 & 0.350 & 0.279 & 0.322 & 21 & $\mathrm{H}$ \\
\hline Bangladesh & 0.060 & 0.071 & 0.094 & 0.076 & 0.075 & 110 & LM \\
\hline Belarus & 0.041 & 0.052 & 0.054 & 0.057 & 0.051 & 120 & UM \\
\hline Belgium & 0.382 & 0.373 & 0.356 & 0.253 & 0.341 & 17 & $\mathrm{H}$ \\
\hline Belize & 0.197 & 0.227 & 0.228 & 0.161 & 0.203 & 55 & UM \\
\hline Bhutan & 0.066 & 0.085 & 0.132 & 0.112 & 0.099 & 101 & $\mathrm{LM}$ \\
\hline Bolivia & & 0.092 & 0.126 & 0.133 & 0.117 & 94 & LM \\
\hline $\begin{array}{l}\text { Bosnia and } \\
\text { Herzegovina }\end{array}$ & 0.157 & 0.217 & 0.237 & 0.173 & 0.196 & 58 & UM \\
\hline Botswana & 0.073 & 0.102 & 0.104 & 0.089 & 0.092 & 106 & UM \\
\hline Brazil & 0.248 & 0.268 & 0.296 & 0.252 & 0.266 & 33 & UM \\
\hline Brunei Darussalam & 0.194 & 0.227 & 0.226 & 0.169 & 0.204 & 53 & $\mathrm{H}$ \\
\hline Bulgaria & 0.310 & 0.434 & 0.440 & 0.297 & 0.370 & 15 & UM \\
\hline Burundi & 0.024 & 0.023 & 0.031 & 0.023 & 0.025 & 138 & $\mathrm{~L}$ \\
\hline Cabo Verde & 0.132 & 0.203 & 0.271 & 0.195 & 0.200 & 56 & LM \\
\hline Cambodia & 0.019 & 0.044 & 0.068 & 0.093 & 0.056 & 117 & LM \\
\hline Cameroon & 0.014 & 0.016 & 0.024 & 0.024 & 0.020 & 144 & LM \\
\hline \multicolumn{2}{|c|}{ Central African Republic } & 0.007 & 0.014 & 0.018 & 0.013 & 148 & $\mathrm{~L}$ \\
\hline Colombia & & 0.167 & 0.314 & 0.328 & 0.270 & 32 & UM \\
\hline Comoros & 0.012 & 0.018 & 0.037 & 0.041 & 0.027 & 137 & $\mathrm{~L}$ \\
\hline Congo. Dem. Rep. & & 0.002 & 0.002 & 0.006 & 0.003 & 152 & $\mathrm{~L}$ \\
\hline Congo. Rep. & 0.004 & 0.006 & 0.018 & 0.031 & 0.015 & 146 & $\mathrm{LM}$ \\
\hline Costa Rica & 0.147 & 0.189 & 0.214 & 0.192 & 0.186 & 63 & UM \\
\hline Croatia & 0.269 & 0.330 & 0.373 & 0.282 & 0.314 & 22 & UM \\
\hline Czech Republic & 0.161 & 0.189 & 0.214 & 0.166 & 0.182 & 65 & $\mathrm{H}$ \\
\hline Chad & 0.002 & 0.000 & 0.003 & 0.009 & 0.004 & 151 & $\mathrm{~L}$ \\
\hline Chile & 0.203 & 0.263 & 0.295 & 0.235 & 0.249 & 42 & $\mathrm{H}$ \\
\hline Denmark & 0.467 & 0.486 & 0.438 & 0.301 & 0.423 & 10 & $\mathrm{H}$ \\
\hline Djibouti & 0.034 & 0.045 & 0.066 & 0.057 & 0.051 & 121 & $\mathrm{LM}$ \\
\hline Dominica & 0.165 & 0.177 & 0.225 & 0.161 & 0.182 & 66 & UM \\
\hline $\begin{array}{l}\text { Dominican } \\
\text { Republic }\end{array}$ & 0.094 & 0.097 & 0.106 & 0.092 & 0.097 & 102 & UM \\
\hline
\end{tabular}




\begin{tabular}{|c|c|c|c|c|c|c|c|}
\hline Country & 04-07 & 07-09 & $09-12$ & $12-15$ & Average & Ranking & $\begin{array}{c}\text { Income } \\
\text { group }\end{array}$ \\
\hline Ecuador & 0.077 & 0.126 & 0.245 & 0.181 & 0.157 & 78 & UM \\
\hline Egypt. Arab Rep. & 0.083 & 0.081 & 0.072 & 0.055 & 0.073 & 111 & LM \\
\hline El Salvador & & 0.139 & 0.138 & 0.117 & 0.131 & 86 & LM \\
\hline Equatorial Guinea & & 0.016 & 0.028 & 0.031 & 0.025 & 139 & UM \\
\hline Estonia & 0.257 & 0.333 & 0.297 & 0.202 & 0.272 & 31 & $\mathrm{H}$ \\
\hline Fiji & 0.152 & 0.191 & 0.200 & 0.176 & 0.180 & 68 & UM \\
\hline Finland & 0.268 & 0.221 & 0.233 & 0.180 & 0.225 & 48 & $\mathrm{H}$ \\
\hline France & 0.343 & 0.426 & 0.439 & 0.317 & 0.381 & 13 & $\mathrm{H}$ \\
\hline Gabon & 0.032 & 0.033 & 0.047 & 0.049 & 0.040 & 129 & UM \\
\hline Georgia & 0.063 & 0.153 & 0.197 & 0.191 & 0.151 & 80 & $\mathrm{LM}$ \\
\hline Germany & & 0.339 & 0.326 & 0.263 & 0.309 & 24 & $\mathrm{H}$ \\
\hline Ghana & & 0.039 & 0.044 & 0.043 & 0.042 & 127 & LM \\
\hline Greece & 0.317 & 0.378 & 0.415 & 0.268 & 0.344 & 16 & $\mathrm{H}$ \\
\hline Grenada & 0.252 & 0.280 & 0.315 & 0.202 & 0.262 & 35 & UM \\
\hline Guatemala & & 0.158 & 0.184 & 0.137 & 0.160 & 76 & LM \\
\hline Guinea & 0.007 & 0.005 & 0.011 & 0.017 & 0.010 & 149 & $\mathrm{~L}$ \\
\hline Guyana & 0.101 & 0.090 & 0.103 & 0.093 & 0.097 & 103 & UM \\
\hline Honduras & 0.117 & 0.169 & 0.179 & 0.140 & 0.151 & 81 & $\mathrm{LM}$ \\
\hline Hungary & 0.170 & 0.217 & 0.219 & 0.147 & 0.188 & 61 & $\mathrm{H}$ \\
\hline Iceland & 0.693 & 0.601 & 0.493 & 0.285 & 0.518 & 3 & $\mathrm{H}$ \\
\hline India & 0.083 & 0.104 & 0.127 & 0.110 & 0.106 & 97 & LM \\
\hline Indonesia & 0.065 & 0.076 & 0.102 & 0.130 & 0.093 & 105 & LM \\
\hline Iran. Islamic Rep. & 0.147 & 0.186 & 0.230 & 0.189 & 0.188 & 62 & UM \\
\hline Ireland & 0.417 & 0.459 & 0.387 & 0.237 & 0.375 & 14 & $\mathrm{H}$ \\
\hline Israel & 0.269 & 0.288 & 0.333 & 0.253 & 0.286 & 27 & $\mathrm{H}$ \\
\hline Italy & 0.390 & 0.456 & 0.478 & 0.317 & 0.410 & 11 & $\mathrm{H}$ \\
\hline Jamaica & 0.081 & 0.095 & 0.095 & 0.083 & 0.089 & 107 & UM \\
\hline Japan & 0.522 & 0.517 & 0.519 & 0.408 & 0.492 & 5 & $\mathrm{H}$ \\
\hline Jordan & & 0.210 & 0.214 & 0.159 & 0.194 & 59 & LM \\
\hline Kazakhstan & 0.082 & 0.153 & 0.141 & 0.132 & 0.127 & 87 & UM \\
\hline Kenya & 0.046 & 0.055 & 0.071 & 0.064 & 0.059 & 115 & $\mathrm{LM}$ \\
\hline Korea. Rep. & 0.434 & 0.490 & 0.506 & 0.424 & 0.463 & 7 & $\mathrm{H}$ \\
\hline Kosovo & 0.110 & 0.147 & 0.180 & 0.126 & 0.141 & 84 & LM \\
\hline Kuwait & 0.170 & 0.215 & 0.218 & 0.190 & 0.198 & 57 & $\mathrm{H}$ \\
\hline Kyrgyz Republic & 0.027 & 0.041 & 0.054 & 0.066 & 0.047 & 125 & LM \\
\hline Lao PDR & 0.012 & 0.023 & 0.050 & & 0.028 & 135 & LM \\
\hline Latvia & 0.264 & 0.349 & 0.328 & 0.179 & 0.280 & 28 & $\mathrm{H}$ \\
\hline Lebanon & 0.246 & 0.259 & 0.286 & 0.218 & 0.252 & 39 & UM \\
\hline Lesotho & 0.020 & 0.025 & 0.039 & 0.042 & 0.031 & 132 & LM \\
\hline Liberia & & 0.020 & 0.034 & 0.031 & 0.028 & 134 & $\mathrm{~L}$ \\
\hline Libya & 0.043 & 0.045 & 0.060 & & 0.049 & 123 & UM \\
\hline Lithuania & 0.195 & 0.267 & 0.254 & & 0.239 & 45 & $\mathrm{H}$ \\
\hline Luxembourg & 0.503 & 0.556 & 0.518 & 0.380 & 0.489 & 6 & $\mathrm{H}$ \\
\hline Macedonia. FYR & 0.108 & 0.193 & 0.224 & 0.173 & 0.175 & 71 & UM \\
\hline Madagascar & 0.016 & 0.017 & 0.018 & 0.019 & 0.017 & 145 & $\mathrm{~L}$ \\
\hline
\end{tabular}




\begin{tabular}{|c|c|c|c|c|c|c|c|}
\hline Country & 04-07 & 07-09 & 09-12 & $12-15$ & Average & Ranking & $\begin{array}{l}\text { Income } \\
\text { group }\end{array}$ \\
\hline Malawi & 0.010 & 0.019 & 0.029 & 0.023 & 0.020 & 143 & $\mathrm{~L}$ \\
\hline Malaysia & 0.217 & 0.240 & 0.262 & 0.230 & 0.237 & 46 & UM \\
\hline Maldives & 0.093 & 0.149 & 0.139 & 0.096 & 0.119 & 92 & UM \\
\hline Malta & 0.326 & 0.363 & 0.392 & 0.268 & 0.337 & 18 & $\mathrm{H}$ \\
\hline Mauritius & 0.207 & 0.233 & 0.271 & 0.225 & 0.234 & 47 & UM \\
\hline Mexico & 0.103 & 0.126 & 0.142 & 0.119 & 0.123 & 90 & UM \\
\hline Moldova & 0.072 & 0.111 & 0.131 & 0.109 & 0.106 & 98 & LM \\
\hline Montenegro & 0.136 & 0.322 & 0.320 & 0.224 & 0.251 & 41 & UM \\
\hline Mongolia & & 0.229 & 0.287 & 0.263 & 0.259 & 38 & LM \\
\hline Morocco & 0.110 & 0.159 & 0.212 & 0.158 & 0.160 & 77 & LM \\
\hline Mozambique & 0.021 & 0.034 & 0.053 & 0.058 & 0.041 & 128 & $\mathrm{~L}$ \\
\hline Namibia & 0.114 & 0.148 & 0.180 & 0.151 & 0.148 & 82 & UM \\
\hline Netherlands & 0.339 & 0.342 & 0.318 & 0.230 & 0.307 & 25 & $\mathrm{H}$ \\
\hline New Zealand & 0.371 & 0.411 & 0.421 & & 0.401 & 12 & $\mathrm{H}$ \\
\hline Nicaragua & 0.055 & 0.079 & 0.076 & 0.072 & 0.071 & 112 & LM \\
\hline Nigeria & 0.031 & 0.075 & 0.051 & 0.041 & 0.050 & 122 & $\mathrm{LM}$ \\
\hline Norway & 0.264 & 0.279 & 0.276 & 0.227 & 0.262 & 37 & $\mathrm{H}$ \\
\hline Pakistan & 0.062 & 0.068 & 0.063 & 0.042 & 0.059 & 116 & LM \\
\hline Panama & & 0.242 & 0.268 & 0.218 & 0.243 & 44 & UM \\
\hline Papua New Guinea & 0.030 & 0.046 & 0.058 & 0.055 & 0.047 & 124 & $\mathrm{LM}$ \\
\hline Paraguay & & 0.069 & 0.116 & 0.115 & 0.100 & 100 & UM \\
\hline Peru & 0.056 & 0.080 & 0.103 & 0.139 & 0.094 & 104 & UM \\
\hline Poland & 0.163 & 0.225 & 0.262 & 0.198 & 0.212 & 51 & $\mathrm{H}$ \\
\hline Portugal & 0.624 & 0.697 & 0.723 & 0.459 & 0.626 & 2 & $\mathrm{H}$ \\
\hline Philippines & 0.082 & 0.083 & 0.095 & 0.093 & 0.088 & 108 & LM \\
\hline Qatar & 0.195 & 0.193 & 0.184 & 0.168 & 0.185 & 64 & $\mathrm{H}$ \\
\hline Romania & & 0.238 & 0.258 & 0.165 & 0.221 & 49 & UM \\
\hline Russian Federation & 0.159 & 0.254 & 0.338 & 0.306 & 0.264 & 34 & UM \\
\hline Rwanda & 0.016 & 0.027 & 0.042 & 0.041 & 0.031 & 131 & $\mathrm{~L}$ \\
\hline Samoa & 0.123 & 0.193 & 0.209 & 0.181 & 0.177 & 70 & UM \\
\hline Saudi Arabia & 0.115 & 0.148 & 0.154 & 0.158 & 0.144 & 83 & $\mathrm{H}$ \\
\hline Serbia & 0.153 & 0.245 & 0.274 & 0.161 & 0.208 & 52 & UM \\
\hline Seychelles & 0.206 & 0.222 & 0.241 & 0.185 & 0.214 & 50 & $\mathrm{H}$ \\
\hline Singapore & 0.229 & 0.240 & 0.264 & 0.243 & 0.244 & 43 & $\mathrm{H}$ \\
\hline Slovak Republic & 0.188 & 0.215 & 0.232 & 0.181 & 0.204 & 54 & $\mathrm{H}$ \\
\hline Slovenia & 0.302 & 0.383 & 0.402 & 0.242 & 0.332 & 19 & $\mathrm{H}$ \\
\hline Solomon Islands & 0.055 & 0.078 & 0.062 & 0.068 & 0.066 & 114 & LM \\
\hline South Africa & 0.223 & 0.264 & 0.294 & 0.266 & 0.262 & 36 & UM \\
\hline Spain & 0.695 & 0.766 & 0.705 & 0.436 & 0.650 & 1 & $\mathrm{H}$ \\
\hline Sri Lanka & & 0.103 & 0.127 & 0.098 & 0.109 & 95 & $\mathrm{LM}$ \\
\hline St. Kitts and Nevis & & 0.349 & 0.371 & 0.262 & 0.327 & 20 & $\mathrm{H}$ \\
\hline St. Lucia & 0.225 & 0.267 & 0.297 & 0.217 & 0.252 & 40 & UM \\
\hline $\begin{array}{l}\text { St. Vincent } \\
\text { and the Grenadines }\end{array}$ & & 0.176 & 0.188 & 0.142 & 0.169 & 73 & UM \\
\hline Sudan & 0.020 & 0.023 & 0.026 & 0.016 & 0.021 & 142 & LM \\
\hline
\end{tabular}




\begin{tabular}{|c|c|c|c|c|c|c|c|}
\hline Country & 04-07 & 07-09 & 09-12 & $12-15$ & Average & Ranking & $\begin{array}{l}\text { Income } \\
\text { group }\end{array}$ \\
\hline Suriname & 0.089 & 0.108 & 0.121 & 0.112 & 0.108 & 96 & UM \\
\hline Swaziland & 0.058 & 0.070 & 0.076 & 0.070 & 0.068 & 113 & LM \\
\hline Sweden & 0.263 & 0.299 & 0.313 & 0.241 & 0.279 & 29 & $\mathrm{H}$ \\
\hline Switzerland & 0.521 & 0.529 & 0.536 & 0.392 & 0.495 & 4 & $\mathrm{H}$ \\
\hline Tajikistan & 0.026 & 0.048 & 0.047 & 0.048 & 0.042 & 126 & LM \\
\hline Tanzania & 0.015 & 0.021 & 0.026 & 0.034 & 0.024 & 140 & $\mathrm{~L}$ \\
\hline Timor-Leste & & 0.027 & 0.027 & 0.029 & 0.028 & 136 & LM \\
\hline Tonga & 0.165 & 0.184 & 0.160 & 0.108 & 0.154 & 79 & UM \\
\hline Tunisia & 0.130 & 0.155 & 0.201 & 0.163 & 0.162 & 74 & LM \\
\hline Turkey & 0.120 & 0.162 & 0.220 & 0.221 & 0.181 & 67 & UM \\
\hline Thailand & 0.190 & 0.267 & 0.326 & 0.320 & 0.276 & 30 & UM \\
\hline $\begin{array}{l}\text { Trinidad and } \\
\text { Tobago }\end{array}$ & & 0.136 & 0.133 & 0.110 & 0.126 & 88 & $\mathrm{H}$ \\
\hline Uganda & 0.016 & 0.023 & 0.030 & 0.025 & 0.023 & 141 & $\mathrm{~L}$ \\
\hline Ukraine & 0.100 & 0.210 & 0.210 & 0.198 & 0.180 & 69 & LM \\
\hline $\begin{array}{l}\text { United Arab } \\
\text { Emirates }\end{array}$ & 0.155 & 0.205 & 0.214 & 0.181 & 0.189 & 60 & $\mathrm{H}$ \\
\hline United Kingdom & 0.457 & 0.481 & 0.462 & 0.364 & 0.441 & 9 & $\mathrm{H}$ \\
\hline Uruguay & 0.115 & 0.118 & 0.127 & 0.113 & 0.118 & 93 & $\mathrm{H}$ \\
\hline Vanuatu & 0.123 & 0.167 & 0.219 & 0.174 & 0.171 & 72 & LM \\
\hline Venezuela. RB & 0.102 & 0.124 & 0.139 & 0.117 & 0.121 & 91 & UM \\
\hline Vietnam & & 0.147 & 0.176 & 0.161 & 0.162 & 75 & LM \\
\hline $\begin{array}{l}\text { West Bank and } \\
\text { Gaza }\end{array}$ & 0.046 & 0.052 & 0.062 & 0.048 & 0.052 & 119 & LM \\
\hline Yemen. Rep. & 0.014 & 0.016 & 0.012 & 0.012 & 0.013 & 147 & LM \\
\hline Zambia & 0.019 & 0.028 & 0.037 & 0.040 & 0.031 & 133 & LM \\
\hline
\end{tabular}

Note: 04-07, 07-09, 09-12, and 12-15 represent the period of 2004-2007, 2007-2009, 2009-2012, and 2012-2015, respectively. The average value is the average number for the whole period of 2004-2015, on which the ranking is relied. The ranking follows the principle that the higher level of the index of financial inclusion shows the lower ranking. The income group is followed the 2016's income classification by World Bank. Four groups including low-. lower middle-, upper middle-, and highincome countries are indicated by L, LM, UM and H, corresponding.

Source: Authors' calculation. 
Table 1: Effect of financial inclusion on economic growth with a proxy of financial inclusion index

\begin{tabular}{|c|c|c|c|c|c|c|c|c|}
\hline & $(1)$ & $(2)$ & (3) & (4) & $(5)$ & $(6)$ & $(7)$ & $(8)$ \\
\hline & Full sample & Low & Lower middle & Upper middle & High & $\mathrm{q} 25$ & $\mathrm{q} 25-75$ & $\mathrm{q} 75$ \\
\hline $\mathrm{GDPPC}_{\mathrm{t}-1}$ & $\begin{array}{c}0.557 * * * \\
(0.065)\end{array}$ & $\begin{array}{c}0.711 * * * \\
(0.132)\end{array}$ & $\begin{array}{c}0.603 * * * \\
(0.174)\end{array}$ & $\begin{array}{c}0.448 * * * \\
(0.129)\end{array}$ & $\begin{array}{c}0.642 * * * \\
(0.096)\end{array}$ & $\begin{array}{c}0.478 * * * \\
(0.142)\end{array}$ & $\begin{array}{c}0.544 * * * \\
(0.095)\end{array}$ & $\begin{array}{c}0.700 * * * \\
(0.138)\end{array}$ \\
\hline $\mathrm{GDPPC}_{2004}$ & $\begin{array}{c}0.399 * * * \\
(0.131)\end{array}$ & $\begin{array}{c}0.113 \\
(0.750)\end{array}$ & $\begin{array}{c}0.066 \\
(0.996)\end{array}$ & $\begin{array}{c}1.005 \\
(0.649)\end{array}$ & $\begin{array}{c}0.151 \\
(0.211)\end{array}$ & $\begin{array}{c}0.439 \\
(0.470)\end{array}$ & $\begin{array}{c}0.259 \\
(0.163)\end{array}$ & $\begin{array}{c}1.417 * * * \\
(0.432)\end{array}$ \\
\hline Population & $\begin{array}{l}-0.049 \\
(0.126)\end{array}$ & $\begin{array}{c}0.164 \\
(0.360)\end{array}$ & $\begin{array}{c}0.143 \\
(0.467)\end{array}$ & $\begin{array}{l}-0.273 \\
(0.301)\end{array}$ & $\begin{array}{c}0.103 \\
(0.092)\end{array}$ & $\begin{array}{c}0.027 \\
(0.216)\end{array}$ & $\begin{array}{c}0.083 \\
(0.070)\end{array}$ & $\begin{array}{c}-0.677 * * * \\
(0.236)\end{array}$ \\
\hline Schooling & $\begin{array}{c}0.056 \\
(0.046)\end{array}$ & $\begin{array}{c}0.031 \\
(0.053)\end{array}$ & $\begin{array}{l}-0.024 \\
(0.093)\end{array}$ & $\begin{array}{c}0.147 * * \\
(0.067)\end{array}$ & $\begin{array}{c}0.015 \\
(0.062)\end{array}$ & $\begin{array}{c}0.004 \\
(0.052)\end{array}$ & $\begin{array}{c}0.027 \\
(0.059)\end{array}$ & $\begin{array}{l}-0.005 \\
(0.047)\end{array}$ \\
\hline Capital & $\begin{array}{c}0.093 * * * \\
(0.031)\end{array}$ & $\begin{array}{c}0.030 \\
(0.034)\end{array}$ & $\begin{array}{c}0.142 * * \\
(0.064)\end{array}$ & $\begin{array}{c}0.185^{* * *} \\
(0.066)\end{array}$ & $\begin{array}{c}0.147 * * \\
(0.058)\end{array}$ & $\begin{array}{c}0.069 \\
(0.051)\end{array}$ & $\begin{array}{c}0.074 * * \\
(0.033)\end{array}$ & $\begin{array}{c}0.242 * * * \\
(0.059)\end{array}$ \\
\hline Expenditure share & $\begin{array}{c}-0.292 * * * \\
(0.099)\end{array}$ & $\begin{array}{l}-0.042 \\
(0.132)\end{array}$ & $\begin{array}{l}-0.147 \\
(0.143)\end{array}$ & $\begin{array}{c}-0.333 * * \\
(0.144)\end{array}$ & $\begin{array}{c}-0.600 * * * \\
(0.190)\end{array}$ & $\begin{array}{l}-0.218 \\
(0.173)\end{array}$ & $\begin{array}{c}-0.280 * * * \\
(0.107)\end{array}$ & $\begin{array}{c}-0.602 * * * \\
(0.168)\end{array}$ \\
\hline Agricultural share & $\begin{array}{l}-0.048 \\
(0.044)\end{array}$ & $\begin{array}{c}-0.299 * \\
(0.154)\end{array}$ & $\begin{array}{c}0.029 \\
(0.084)\end{array}$ & $\begin{array}{c}-0.109 * \\
(0.065)\end{array}$ & $\begin{array}{l}-0.039 \\
(0.055)\end{array}$ & $\begin{array}{l}-0.054 \\
(0.077)\end{array}$ & $\begin{array}{c}-0.123 * \\
(0.073)\end{array}$ & $\begin{array}{c}0.084 \\
(0.080)\end{array}$ \\
\hline Trade Openness & $\begin{array}{l}-0.005 \\
(0.035)\end{array}$ & $\begin{array}{l}-0.011 \\
(0.064)\end{array}$ & $\begin{array}{c}0.035 \\
(0.082)\end{array}$ & $\begin{array}{c}0.043 \\
(0.059)\end{array}$ & $\begin{array}{l}-0.095 \\
(0.068)\end{array}$ & $\begin{array}{c}0.030 \\
(0.045)\end{array}$ & $\begin{array}{c}0.043 \\
(0.050)\end{array}$ & $\begin{array}{l}-0.152 \\
(0.100)\end{array}$ \\
\hline Financial Inclusion Index & $\begin{array}{c}0.050 * * * \\
(0.014)\end{array}$ & $\begin{array}{c}0.058 * * \\
(0.025)\end{array}$ & $\begin{array}{c}0.043 \\
(0.039)\end{array}$ & $\begin{array}{c}0.046 \\
(0.034)\end{array}$ & $\begin{array}{l}-0.048 \\
(0.095)\end{array}$ & $\begin{array}{l}0.037 * \\
(0.020)\end{array}$ & $\begin{array}{c}0.086 * * * \\
(0.029)\end{array}$ & $\begin{array}{c}0.004 \\
(0.040)\end{array}$ \\
\hline Constant & $\begin{array}{c}0.760 \\
(1.171)\end{array}$ & $\begin{array}{c}0.000 \\
(0.000)\end{array}$ & $\begin{array}{c}0.000 \\
(0.000)\end{array}$ & $\begin{array}{c}0.000 \\
(0.000)\end{array}$ & $\begin{array}{c}0.000 \\
(0.000)\end{array}$ & $\begin{array}{c}0.000 \\
(0.000)\end{array}$ & $\begin{array}{c}0.000 \\
(0.000)\end{array}$ & $\begin{array}{c}0.000 \\
(0.000)\end{array}$ \\
\hline Time dummy & Yes & Yes & Yes & Yes & Yes & Yes & Yes & Yes \\
\hline Country dummy & Yes & Yes & Yes & Yes & Yes & Yes & Yes & Yes \\
\hline Observations & 328 & 31 & 88 & 96 & 113 & 69 & 154 & 105 \\
\hline Number of countries & 124 & 12 & 35 & 37 & 40 & 28 & 60 & 36 \\
\hline
\end{tabular}


Table 2: Effect of financial inclusion on economic growth with a proxy of ATMs

\begin{tabular}{|c|c|c|c|c|c|c|c|c|}
\hline & (1) & (2) & (3) & (4) & $(5)$ & (6) & (7) & $(8)$ \\
\hline & Full sample & Low & Lower middle & Upper middle & High & $\mathrm{q} 25$ & $\mathrm{q} 25-75$ & $\mathrm{q} 75$ \\
\hline \multirow[t]{2}{*}{$\mathrm{GDPPC}_{\mathrm{t}-1}$} & $0.535 * * *$ & $0.576 * * *$ & $0.535 * * *$ & $0.477 * * *$ & $0.557 * * *$ & $0.452 * * *$ & $0.550 * * *$ & $0.611 * * *$ \\
\hline & $(0.071)$ & $(0.155)$ & $(0.203)$ & $(0.129)$ & $(0.103)$ & $(0.132)$ & $(0.102)$ & $(0.077)$ \\
\hline \multirow[t]{2}{*}{ GDPPC2004 } & $0.473 * * *$ & 0.617 & 0.426 & $0.744^{*}$ & 0.341 & 0.594 & 0.248 & $1.379 * * *$ \\
\hline & $(0.144)$ & (1.412) & (1.081) & $(0.446)$ & $(0.288)$ & $(0.573)$ & $(0.159)$ & $(0.429)$ \\
\hline \multirow[t]{2}{*}{ Population } & -0.085 & 0.030 & -0.020 & -0.288 & 0.029 & -0.038 & 0.062 & $-0.617 * * *$ \\
\hline & $(0.137)$ & $(0.607)$ & $(0.487)$ & $(0.311)$ & $(0.132)$ & $(0.272)$ & $(0.066)$ & $(0.236)$ \\
\hline \multirow[t]{2}{*}{ Schooling } & 0.025 & -0.056 & -0.018 & $0.178 * * *$ & 0.007 & -0.028 & 0.035 & -0.020 \\
\hline & $(0.047)$ & $(0.069)$ & $(0.111)$ & $(0.068)$ & $(0.060)$ & $(0.063)$ & $(0.066)$ & $(0.049)$ \\
\hline \multirow[t]{2}{*}{ Capital } & $0.101 * * *$ & $0.060 * * *$ & $0.135^{* *}$ & $0.212 * * *$ & $0.129 * *$ & $0.078 * *$ & $0.086 * *$ & $0.239 * * *$ \\
\hline & $(0.030)$ & $(0.017)$ & $(0.064)$ & $(0.068)$ & $(0.055)$ & $(0.039)$ & $(0.040)$ & $(0.057)$ \\
\hline \multirow[t]{2}{*}{ Expenditure share } & $-0.234 * *$ & 0.169 & -0.124 & $-0.298 * *$ & $-0.666 * * *$ & -0.124 & $-0.254 * *$ & $-0.627 * * *$ \\
\hline & $(0.099)$ & $(0.159)$ & $(0.150)$ & $(0.133)$ & $(0.159)$ & $(0.178)$ & $(0.111)$ & $(0.120)$ \\
\hline \multirow[t]{2}{*}{ Agricultural share } & -0.067 & $-0.377 *$ & -0.003 & $-0.106^{*}$ & -0.022 & -0.089 & $-0.127 *$ & 0.093 \\
\hline & $(0.047)$ & $(0.214)$ & $(0.094)$ & $(0.061)$ & $(0.051)$ & $(0.092)$ & $(0.077)$ & $(0.082)$ \\
\hline \multirow[t]{2}{*}{ Trade Openness } & 0.006 & -0.031 & 0.052 & 0.032 & -0.096 & 0.038 & 0.054 & $-0.136^{*}$ \\
\hline & $(0.037)$ & $(0.087)$ & $(0.075)$ & $(0.065)$ & $(0.062)$ & $(0.048)$ & $(0.054)$ & $(0.080)$ \\
\hline \multirow[t]{2}{*}{ ATMs } & $0.032 * *$ & 0.028 & 0.046 & -0.011 & 0.060 & 0.024 & 0.028 & 0.051 \\
\hline & $(0.016)$ & $(0.019)$ & $(0.039)$ & $(0.049)$ & $(0.056)$ & $(0.023)$ & $(0.022)$ & $(0.081)$ \\
\hline \multirow[t]{2}{*}{ Constant } & 0.793 & 0.000 & 0.000 & 0.000 & 0.000 & 0.000 & 0.000 & 0.000 \\
\hline & $(1.332)$ & $(0.000)$ & $(0.000)$ & $(0.000)$ & $(0.000)$ & $(0.000)$ & $(0.000)$ & $(0.000)$ \\
\hline Time dummy & Yes & Yes & Yes & Yes & Yes & Yes & Yes & Yes \\
\hline Country dummy & Yes & Yes & Yes & Yes & Yes & Yes & Yes & Yes \\
\hline Observations & 331 & 31 & 89 & 96 & 115 & 70 & 155 & 106 \\
\hline Number of countries & 124 & 12 & 35 & 37 & 40 & 28 & 60 & 36 \\
\hline
\end{tabular}

Note: Please refer to note in Table 1.

Source: Authors' calculation. 
Table 3: Effect of financial inclusion on economic growth with a proxy of the number of bank branches

\begin{tabular}{|c|c|c|c|c|c|c|c|c|}
\hline & (1) & (2) & (3) & (4) & (5) & (6) & (7) & (8) \\
\hline & Full sample & Low & Lower middle & Upper middle & High & $\mathrm{q} 25$ & $\mathrm{q} 25-75$ & $\mathrm{q} 75$ \\
\hline \multirow[t]{2}{*}{$\mathrm{GDPPC}_{\mathrm{t}-1}$} & $0.582 * * *$ & $0.630 * * *$ & $0.629 * * *$ & $0.478 * * *$ & $0.630 * * *$ & $0.488 * * *$ & $0.594 * * *$ & $0.676 * * *$ \\
\hline & $(0.064)$ & $(0.115)$ & $(0.178)$ & $(0.128)$ & $(0.077)$ & $(0.150)$ & $(0.085)$ & $(0.139)$ \\
\hline \multirow[t]{2}{*}{ GDPPC2004 } & $0.390 * * *$ & 0.488 & 0.369 & 1.003 & 0.205 & 0.726 & 0.186 & $1.450 * * *$ \\
\hline & $(0.135)$ & $(1.690)$ & $(1.090)$ & $(0.653)$ & $(0.205)$ & $(0.536)$ & $(0.146)$ & $(0.411)$ \\
\hline \multirow[t]{2}{*}{ Population } & -0.054 & 0.132 & -0.041 & -0.294 & 0.090 & -0.115 & 0.091 & $-0.684 * * *$ \\
\hline & $(0.134)$ & $(0.736)$ & $(0.498)$ & $(0.304)$ & $(0.095)$ & $(0.272)$ & $(0.067)$ & $(0.226)$ \\
\hline \multirow[t]{2}{*}{ Schooling } & 0.050 & -0.066 & 0.007 & $0.154 * *$ & 0.008 & -0.028 & 0.026 & -0.009 \\
\hline & $(0.047)$ & $(0.041)$ & $(0.099)$ & $(0.070)$ & $(0.059)$ & $(0.062)$ & $(0.060)$ & $(0.045)$ \\
\hline \multirow[t]{2}{*}{ Capital } & $0.101 * * *$ & $0.045^{*}$ & $0.139 * *$ & $0.200 * * *$ & $0.153^{* * *}$ & $0.079 *$ & $0.080 * *$ & $0.235^{* * *}$ \\
\hline & $(0.031)$ & $(0.027)$ & $(0.066)$ & $(0.068)$ & $(0.057)$ & $(0.042)$ & $(0.039)$ & $(0.060)$ \\
\hline \multirow[t]{2}{*}{ Expenditure share } & $-0.198 *$ & $0.336 * * *$ & -0.057 & $-0.273^{*}$ & $-0.640 * * *$ & -0.019 & $-0.212 * *$ & $-0.605 * * *$ \\
\hline & $(0.111)$ & $(0.080)$ & $(0.185)$ & $(0.140)$ & $(0.161)$ & $(0.238)$ & $(0.104)$ & $(0.149)$ \\
\hline \multirow[t]{2}{*}{ Agricultural share } & -0.058 & $-0.565 * *$ & -0.002 & $-0.107 *$ & -0.043 & -0.104 & -0.105 & 0.091 \\
\hline & $(0.048)$ & $(0.252)$ & $(0.091)$ & $(0.063)$ & $(0.055)$ & $(0.098)$ & $(0.073)$ & $(0.080)$ \\
\hline \multirow[t]{2}{*}{ Trade Openness } & 0.000 & -0.051 & 0.046 & 0.035 & -0.092 & 0.023 & 0.038 & -0.159 \\
\hline & $(0.038)$ & $(0.081)$ & $(0.082)$ & $(0.059)$ & $(0.067)$ & $(0.055)$ & $(0.053)$ & $(0.100)$ \\
\hline \multirow[t]{2}{*}{ Bank branches } & $0.031 * *$ & $0.316^{* *}$ & 0.034 & 0.015 & -0.043 & 0.057 & $0.043 *$ & 0.018 \\
\hline & $(0.015)$ & $(0.154)$ & $(0.035)$ & $(0.012)$ & $(0.057)$ & $(0.059)$ & $(0.022)$ & $(0.012)$ \\
\hline \multirow[t]{2}{*}{ Constant } & 0.527 & 0.000 & 0.000 & 0.000 & 0.000 & 0.000 & 0.000 & 0.000 \\
\hline & $(1.285)$ & $(0.000)$ & $(0.000)$ & $(0.000)$ & $(0.000)$ & $(0.000)$ & $(0.000)$ & $(0.000)$ \\
\hline Time dummy & Yes & Yes & Yes & Yes & Yes & Yes & Yes & Yes \\
\hline Country dummy & Yes & Yes & Yes & Yes & Yes & Yes & Yes & Yes \\
\hline Observations & 330 & 31 & 89 & 96 & 114 & 70 & 154 & 106 \\
\hline Number of countries & 124 & 12 & 35 & 37 & 40 & 28 & 60 & 36 \\
\hline
\end{tabular}

Note: Please refer to note in Table 1.

Source: Authors' calculation. 
Table 4: Effect of financial inclusion on economic growth with a proxy of the ratio of private credit over GDP

\begin{tabular}{|c|c|c|c|c|c|c|c|c|}
\hline & (1) & $(2)$ & (3) & (4) & $(5)$ & $(6)$ & (7) & $(8)$ \\
\hline & Full sample & Low & Lower middle & Upper middle & High & $\mathrm{q} 25$ & $q 25-75$ & q75 \\
\hline \multirow[t]{2}{*}{$\mathrm{GDPPC}_{\mathrm{t}-1}$} & $0.580 * * *$ & $0.720 * * *$ & $0.596 * * *$ & $0.461 * * *$ & $0.664 * * *$ & $0.474 * * *$ & $0.600 * * *$ & $0.705 * * *$ \\
\hline & $(0.065)$ & $(0.132)$ & $(0.168)$ & $(0.128)$ & $(0.065)$ & $(0.142)$ & $(0.098)$ & $(0.139)$ \\
\hline \multirow[t]{2}{*}{ GDPPC2004 } & $0.401 * * *$ & -1.968 & 0.021 & $0.800 *$ & 0.204 & 0.325 & 0.172 & $1.411 * * *$ \\
\hline & $(0.133)$ & (1.916) & $(0.961)$ & $(0.455)$ & $(0.196)$ & $(0.530)$ & $(0.172)$ & $(0.426)$ \\
\hline \multirow[t]{2}{*}{ Population } & -0.047 & 0.963 & 0.146 & -0.322 & 0.087 & 0.078 & 0.081 & $-0.677 * * *$ \\
\hline & $(0.126)$ & $(0.737)$ & $(0.454)$ & $(0.323)$ & $(0.088)$ & $(0.231)$ & $(0.077)$ & $(0.240)$ \\
\hline \multirow[t]{2}{*}{ Schooling } & 0.066 & 0.084 & -0.002 & $0.158 * *$ & 0.006 & 0.001 & 0.057 & -0.005 \\
\hline & $(0.050)$ & $(0.098)$ & $(0.090)$ & $(0.067)$ & $(0.056)$ & $(0.055)$ & $(0.066)$ & $(0.047)$ \\
\hline \multirow[t]{2}{*}{ Capital } & $0.103 * * *$ & 0.001 & $0.144 * *$ & $0.192 * * *$ & $0.131 * *$ & 0.070 & $0.089 * *$ & $0.244 * * *$ \\
\hline & $(0.033)$ & $(0.073)$ & $(0.064)$ & $(0.067)$ & $(0.056)$ & $(0.054)$ & $(0.038)$ & $(0.055)$ \\
\hline \multirow[t]{2}{*}{ Expenditure share } & $-0.285 * * *$ & -0.461 & -0.160 & $-0.298 * *$ & $-0.486 * * *$ & -0.227 & $-0.270 * *$ & $-0.593 * * *$ \\
\hline & $(0.095)$ & $(0.494)$ & $(0.131)$ & $(0.144)$ & $(0.185)$ & $(0.146)$ & $(0.113)$ & $(0.197)$ \\
\hline \multirow[t]{2}{*}{ Agricultural share } & -0.045 & -0.286 & 0.033 & $-0.113^{*}$ & -0.050 & -0.069 & -0.107 & 0.083 \\
\hline & $(0.045)$ & $(0.176)$ & $(0.082)$ & $(0.062)$ & $(0.054)$ & $(0.081)$ & $(0.075)$ & $(0.082)$ \\
\hline \multirow[t]{2}{*}{ Trade Openness } & -0.009 & -0.045 & 0.027 & 0.022 & -0.082 & 0.009 & 0.039 & -0.152 \\
\hline & $(0.035)$ & $(0.066)$ & $(0.081)$ & $(0.063)$ & $(0.065)$ & $(0.048)$ & $(0.054)$ & $(0.100)$ \\
\hline \multirow[t]{2}{*}{ Credit/GDP } & 0.034 & 0.164 & 0.048 & 0.048 & $-0.079 *$ & $0.054 *$ & 0.024 & -0.001 \\
\hline & $(0.022)$ & $(0.101)$ & $(0.037)$ & $(0.052)$ & $(0.046)$ & $(0.027)$ & $(0.031)$ & $(0.040)$ \\
\hline \multirow[t]{2}{*}{ Constant } & 0.212 & 0.000 & 0.000 & 0.000 & 0.000 & 0.000 & 0.000 & 0.000 \\
\hline & $(1.121)$ & $(0.000)$ & $(0.000)$ & $(0.000)$ & $(0.000)$ & $(0.000)$ & $(0.000)$ & $(0.000)$ \\
\hline Time dummy & Yes & Yes & Yes & Yes & Yes & Yes & Yes & Yes \\
\hline Country dummy & Yes & Yes & Yes & Yes & Yes & Yes & Yes & Yes \\
\hline Observations & 329 & 31 & 88 & 96 & 114 & 69 & 155 & 105 \\
\hline Number of countries & 124 & 12 & 35 & 37 & 40 & 28 & 60 & 36 \\
\hline
\end{tabular}

Note: Please refer to note in Table 1.

Source: Authors' calculation. 